\title{
Structure of Rhodotorucine $A$, a Peptidyl Factor, Inducing Mating Tube Formation in Rhodosporidium toruloides
}

\author{
Yuji KamiYa, Akira Sakurai, Saburo Tamura, Nobutaka Takahashl, \\ Eiko TsuchIYA, ${ }^{*}$ Keiko ABE* and Sakuzo FukUI* \\ The Institute of Physical and Chemical Research, Wako-shi, Saitama-ken 351 \\ *The Institute of Applied Microbiology, The University of Tokyo, \\ Bunkyo-ku, Tokyo 113
}

Received October 6, 1978

\begin{abstract}
Rhodotorucine $\boldsymbol{A}$, which induces mating tube formation in Rhodospridium toruloides, was found to be a novel peptide composed of eleven amino acid residues with a lipophilic group at the $\mathrm{C}$-terminus. The amino acid sequence of the peptide was determined by Edman degradation and enzymatic hydrolyses. The $\mathrm{C}$-terminus of rhodotorucine $\boldsymbol{A}$ was revealed to be S-farnesylcysteine by proton magnetic resonance, mass spectrometry and chemical synthesis. We proposed the following structure for rhodotorucine $A$.
\end{abstract}

H-Tyr-Pro-Glu-Ile-Ser-Trp-Thr-Arg-Asn-Gly-Cys(S-farnesyl)-OH.

In the sexual process of Rhodosporidium toruloides, two mating type cells designated as type $A$ and $a$ conjugate to form filamentous dikaryon mycelium. ${ }^{1}$ At the initial stage of this process, $A$ type cells secrete a peptidyl factor, which induces the mating tube formation of $a$ type cells. ${ }^{2}$ ) Recently, we have succeeded in the isolation ${ }^{3,4)}$ of the factor named as rhodotorucine $A$, and reported its structure preliminarily. ${ }^{5,6}$ ) In this paper, we wish to describe the structural determination of rhodotorucine $A$ in detail.

Based on the amino acid analysis of the acid hydrolyzate (Table 1 ), the composition of ten amino acid residues in rhodotorucine $A$ was established as Asp 1, Thr 1, Ser 1, Glu 1, Pro 1, Gly 1, Ile 1, Tyr 1, Trp 1 and Arg 1. The UV spectrum (Fig. 1) also indicated that the peptide contained one residue each of tryptophan and tyrosine. Besides these amino acids, about 0.05 molar ratio of cystine and trace amount of cysteic acid were observed in the amino acid analysis. Treatment of rhodotorucine $A$ with performic acid followed by acid hydrolysis did not recover one molar ratio of cysteic acid. This suggested the presence of an unknown amino acid which was decomposed on acid hydrolysis to give a trace of cystine and cysteic acid.
$\mathrm{N}$-Terminal amino acid was determined by dansyl (DNS) method with some modifications." After hydrolysis of dansylated peptide with $5.7 \mathrm{~N} \mathrm{HCl}$, DNS-amino acid was detected by a thin-layer chromatography (TLC) on polyamide sheets. As O, N-di-DNS-Tyr, N-DNS-Tyr and O-DNS-Tyr were identified on TLC, N-terminus of rhodotorucine $A$ was determined to be tyrosine.

Then, we applied Edman dansyl procedure for the sequence analysis. Edman degradation was performed according to the procedure described by Hartley ${ }^{8 /}$ by use of $40 \mu \mathrm{g}$ of the peptide with the scaling down method. ${ }^{7}$ At the fifth step of degradation, no DNS-amino acid was detected. This suggested the occurrence of tryptophan in this position, which was further confirmed by enzymatic hydrolyses as described later. Thus the DNS-amino acids up to the eighth step were identified as shown in Table II.

In order to differentiate glutamic acid and glutamine or aspartic acid and asparagine, direct Edman degradation was carried out by use of $200 \mu \mathrm{g}$ of rhodotorucine $A$. The phenylthiohydantoin (PTH) amino acid was identified on polyamide TLC with a fluoresence indicator.9) At the third step of degradation, only PTH-Glu was detected and there was no 
Table I. amino Acid Compositions of the Acid Hydrolyzates of Rhodotorucine $A$ and Its Fragments

\begin{tabular}{|c|c|c|c|c|c|c|c|c|}
\hline & Rhodo. $A$ & Rhodo. $A^{a}$ & $\mathrm{Tr}-1$ & $\mathrm{Tr}-2$ & $\mathrm{CT}-2$ & CT-2 & Th-1 & Th- \\
\hline Cys-SO ${ }_{3} \mathrm{H}$ & 0.02 & 0.15 & - & 0.01 & - & - & - & - \\
\hline Asp & 1.05 & 1.05 & - & 0.98 & - & 一 & - & - \\
\hline Thr & 0.92 & 0.89 & 1.07 & - & - & 1.13 & - & - \\
\hline Ser & 0.82 & 0.71 & 1.04 & - & 0.90 & - & - & 0.80 \\
\hline Glu & 1.08 & 0.95 & 1.02 & - & 1.03 & - & 1.00 & - \\
\hline Pro & 0.86 & 0.93 & 0.85 & - & 0.76 & - & 0.75 & - \\
\hline Gly & 1.00 & 0.96 & - & 1.00 & - & - & - & - \\
\hline$(\mathrm{Cys})_{2}$ & 0.05 & - & - & 0.05 & - & - & - & - \\
\hline Ile & 1.00 & 1.00 & 1.00 & 一 & 1.00 & - & - & 1.00 \\
\hline Tyr & 0.95 & - & 0.88 & - & 0.87 & - & 1.00 & - \\
\hline Trp & 0.86 & - & 0.87 & - & 0.85 & - & - & 0.69 \\
\hline Arg & 1.08 & 0.97 & 1.02 & - & - & 1.00 & - & - \\
\hline
\end{tabular}

a Hydrolysis after oxidized by performic acid.

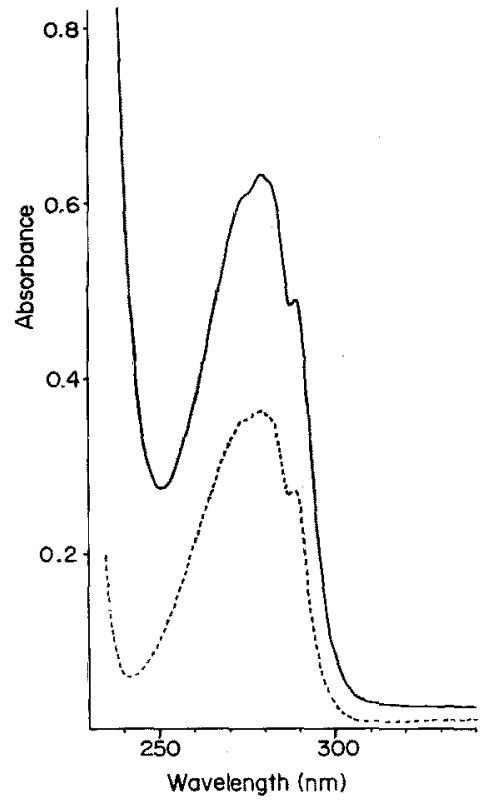

FIG. 1. UV Spectra of Rhodotorucine $A$ and an Equimolar Mixture of Tryptophan and Tyrosine.

$\mathrm{ml}$ in $\mathrm{MeOH}-1 \% \mathrm{AcOH}$; -----, tryptophan and tyrosine at a concentration of $0.05 \mu \mathrm{mol} / \mathrm{ml}$ each in $\mathrm{MeOH}$. trace of PTH-Gln. As a result, the sequence of H-Tyr-Pro-Glu- was confirmed. Further degradation, however, was limited by the loss of the sample during the solvent extraction process. The presence of asparagine in the ninth position was identified by hydrolysis with aminopeptidase $\mathrm{M}$.

Rhodotorucine $A$ was digested with several peptidases to confirm the peptide sequence and to identify the C-terminus of the peptide. Treatment of the lyophilized powder of rhodotorucine $A$ with trypsin in ammonium acetate buffer gave two peptide fragments $\operatorname{Tr}-1$ and $\operatorname{Tr}-2$. Tr -2 which contained C-terminus was easily extracted with $n$-butanol, while $\operatorname{Tr}-1$ remained in the aqueous phase. $\mathrm{Tr}-1$ containing tyrosine and tryptophan was digested with $\alpha$-chymotrypsin to give two fragments CT-1 and CT -2 . CT-1 gave further fragments Th-1 and $T h-3$ on digestion with thermolysin. Each peptide fragment was purified on Sephadex G-25 as shown in Fig. 2. Amino acid compositions (Table I) and $\mathrm{N}$-terminal amino acid of each fragment confirmed the proposed sequence of rhodotorucine $A$ as shown in Table III.

Table II. Sequence Analysis of Rhodotorucine $A$ by Edman Degradations

\begin{tabular}{cccccccccc}
\hline & N-Terminus & 1 & 2 & 3 & 4 & 5 & 6 & 7 & 8 \\
\hline DNS-amino acid & O,N-di-Tyr & & & & & \\
& N-Tyr O-Tyr & Pro & Glu & Ile & Ser & - & Thr & Arg & Asp \\
PHT-amino acid & Tyr & Pro & Glu & - & - & - & - & - \\
\hline Possible sequence & Tyr-Pro-Glu-Ile-Ser-Trp-Thr-Arg-Asx- & &
\end{tabular}




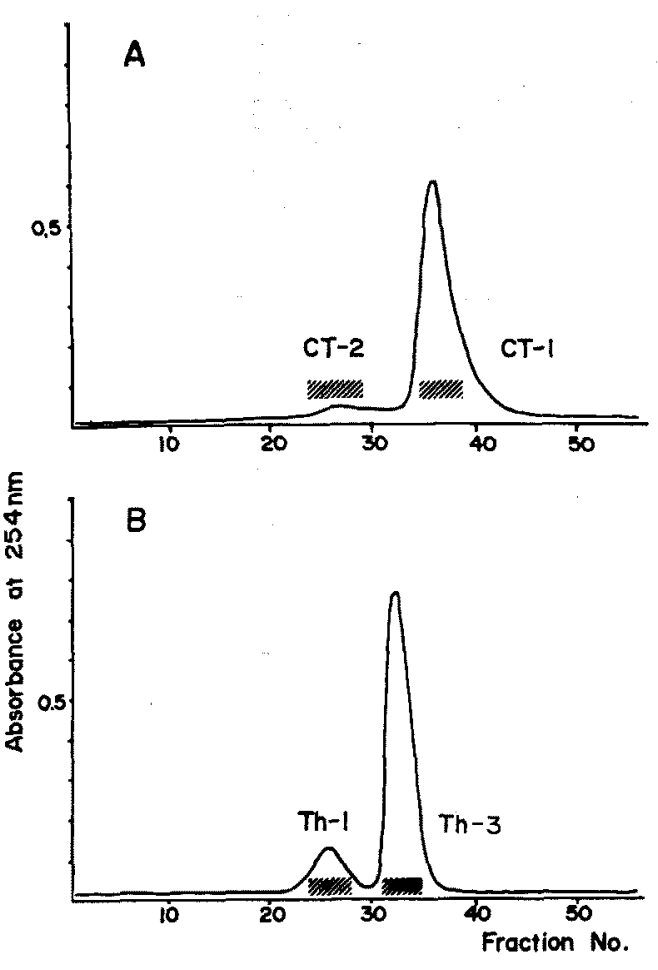

FIG. 2. Chromatography of Peptide Fragments on Sephadex G-25 Column $(1.0 \times 68 \mathrm{~cm})$.

Fraction size, $1.85 \mathrm{ml}$; flow rate, $8.1 \mathrm{ml} / \mathrm{hr}$; 摞urtiu, peptide fragments. A) Hydrolyzate of $\mathrm{Tr}-1$ with a-chymotrypsin. B) Hydrolyzate of $\mathrm{CT}-1$ with thermolysin.

Tr-2 gave colorless crystals when recrystallized from aqueous methanol. Hydrolysis of Tr-2 with aminopeptidase M liberated asparagine, glycine and an unknown amino acid. On acid hydrolysis with $5.7 \mathrm{~N} \mathrm{HCl}, T r-2$ gave aspartic acid, glycine and small amounts of cystine and cysteic acid. As $\mathrm{Tr}-2$ was insoluble in water and easily extracted with $n$ butanol, the unknown amino acid would contain a lipophilic moiety and a cysteine residue.

The structure of the lipophilic amino acid was disclosed by Fourier transfer proton magnetic resonance (FT-PMR) and mass spectrometric analyses of $\operatorname{Tr}-2$. As shown in Fig. 3, the FT-PMR spectrum of $\mathrm{Tr}-2$ revealed the signals characteristic of a farnesyl moiety; four vinyl methyl protons at $\delta 1.60$ $(6 \mathrm{H})$ and $1.66(6 \mathrm{H})$, allyl methylene protons at $\delta 2.0(8 \mathrm{H})$ and vinyl methine protons at $\delta 5.0 \sim 5.3(3 \mathrm{H}) . \quad$ Moreover, signals at $\delta 2.6 \sim$ 3.5 attributable to methylene protons of asparagine and cysteine and to S-allyl methylene protons $\left(\mathrm{S}-\mathrm{CH}_{2}-\mathrm{CH}=\mathrm{CH}-\right.$ ) were observed together with solvent signals. This suggested that cysteine and farnesyl moieties constitute the unknown amino acid.

$\operatorname{Tr}-2$ was acetylated with a mixture of acetic anhydride and acetic anhydride $d_{6}(1: 1)$ in methanol. In this condition carboxyl group was esterified with methanol. The chemical ionization (CI) mass spectrum of the product is shown in Fig. 4. Singlet fragment ion peaks are easily distinguishable from doublet ion peaks containing acetylated $\mathrm{N}$-terminus. ${ }^{10\rangle}$ Among the former, the peaks at $m / e$ 69, 137, 205 and 239 are considered to have originated from the S-farnesyl moiety. Strong doublet ion peaks $m / e$ $157(160)$ and 214 (217) are unambiguously identified as [Ac-Asn] $]^{+}$and $[\mathrm{Ac}-\mathrm{Asn}-\mathrm{Gly}]^{+}$. Other doublet ion peaks larger than $\mathrm{m} / \mathrm{e} 214$ (217) must contain the fragments of the unknown amino acid. Significant doublet ion peaks $m / e 332$ (335) and 536 (539) are explained as [Ac-Asn-Gly-Cys $\mathrm{S}-$-)-OMe] ${ }^{+} \mathrm{H}-\mathrm{NH}_{3}$ and [Ac-Asn-Gly-Cys (S-farnesyl)-OMe $]^{+} \mathrm{H}-\mathrm{NH}_{3}$ respectively. The high resolution electron impact ionization (EI) mass spectrum of acetylated $\operatorname{Tr}-2$ methyl ester did not give the parent ion, but it revealed the peaks with the following element compositions; $69\left(\mathrm{C}_{5} \mathrm{H}_{9}\right), 137\left(\mathrm{C}_{10} \mathrm{H}_{17}\right), 204\left(\mathrm{C}_{10} \mathrm{H}_{24}\right)$, $237\left(\mathrm{C}_{15} \mathrm{H}_{25} \mathrm{~S}_{1}\right), 157\left(\mathrm{C}_{6} \mathrm{H}_{9} \mathrm{~N}_{2} \mathrm{O}_{3}\right), 214\left(\mathrm{C}_{8} \mathrm{H}_{12} \mathrm{~N}_{2}\right.$ $\left.\mathrm{O}_{3}\right)$ and $332\left(\mathrm{C}_{12} \mathrm{H}_{18} \mathrm{~N}_{3} \mathrm{O}_{6} \mathrm{~S}_{1}\right)$. These data strongly support the assumption of the ion structures in the CI mass spectrum. Thus, the structure of H-Asn-Gly-Cys(S-farnesyl)$\mathrm{OH}$ was proposed for $\mathrm{Tr}-2$.

Table III. Enzymatic Hydrolyses of Rhodotorucine $A$

\begin{tabular}{lcccc}
\hline Peptide fragment & Th-1 & Th-3 & CT-2 & Tr-2 \\
N-Terminal amino acid & Tyr & Ile & Thr & Asn \\
Amino acid sequence & Tyr-Pro-Glu & Ile-Ser-Trp & Thr-Arg & Asn-Gly-X \\
\hline
\end{tabular}




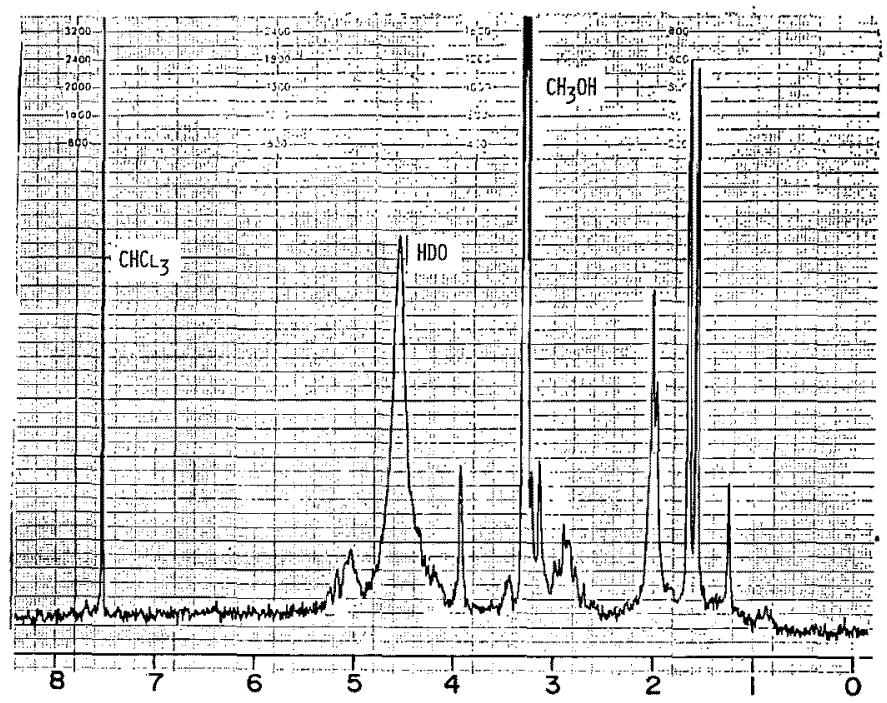

FIG. 3. FT-PMR Spectrum of Tr-2 in $\mathrm{CDCl}_{3}: \mathrm{CD}_{3} \mathrm{OD}: \mathrm{D}_{2} \mathrm{O}(1: 1: 1), 100 \mathrm{MHz}$, Pulse, $42 \mu \mathrm{sec}$; Interval, $5 \mathrm{sec}$; Repetition, 46 Times.

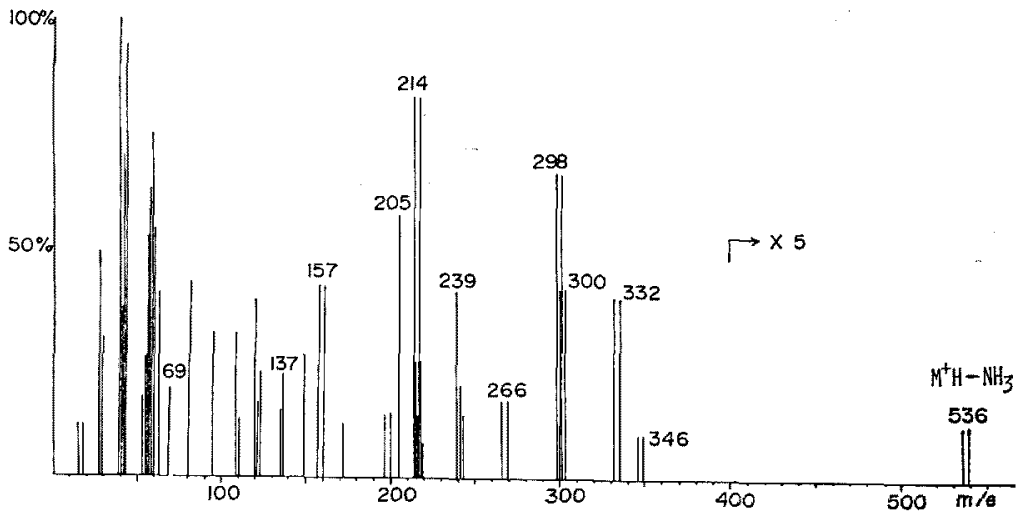

FIG. 4. CI-mass Spectrum of Acetylated Tr-2 Methylester.

Sample temp., $150^{\circ} \mathrm{C}$; reactant gas, isobutane $(99.99 \%)$; ion accelerating voltage, $100 \mathrm{eV}$.

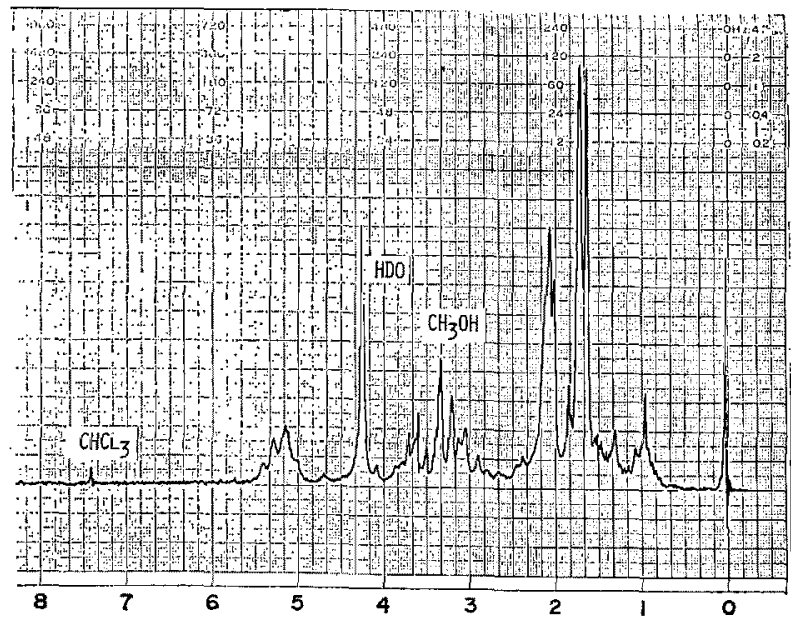

FIG. 5. PMR Spectrum of S-trans-trans-Farnesylcysteine in $\mathrm{CDCl}_{3}: \mathrm{CD}_{3} \mathrm{OD}: \mathrm{D}_{2} \mathrm{O}(1: 1: 1)$. 
For further confirmation, synthesis of $\mathrm{Tr}-2$ using $\mathrm{L}$-amino acids was performed as follows. * Asn-Gly-Cys (SH)-OH was treated with farnesyl bromide in a mixture of methanol- $n$ butanol-water $(1: 1: 1)$ containing an excess amount of sodium bicarbonate. The reaction mixture was purified on Sephadex LH-20 column with methanol to give H-Asn-GlyCys(S-farnesyl)-OH, though the yield was poor. $R f$ values of the synthetic peptide on silica gel TLC in several solvent systems were identical with those of natural $\mathrm{Tr}-2$. The mass spectrum of Ac-Asn-Gly-Cys ( $\mathrm{S}$-farnesyl)-OMe was also identical with that of natural acetylated $\operatorname{Tr}-2$ methyl ester. Therefore, the structure of $\mathrm{Tr}-2$ was confirmed as H-AsnGly-Cys (S-farnesyl)-OH.

The stereochemistry of the farnesyl moiety was predicted to be all trans based on the chemical shifts of methyl protons of $\mathrm{Tr}-2$ in $\mathrm{CDCl}_{3}: \mathrm{CD}_{3} \mathrm{OD}: \mathrm{D}_{2} \mathrm{O}(1: 1: 1)$ as compared with trans-trans-farnesol. ${ }^{11}$ To confirm this, S-trans-trans-farnesylcysteine was synthesized from cysteine and trans-trans-farnesylbromide. As shown in Fig. 5, the chemical shifts of methyl protons of S-trans-trans-farnesylcysteine were identical with those of natural Tr-2. Thus, the stereochemistry of farnesyl moiety was decided to be all trans.

Consequently, we proposed the structure (I) for rhodotorucine $A$ peptide named $\alpha$ substance- $\mathrm{I}_{\mathbf{A}}$ or $\alpha$ factor has been isolated as the regulator of the mating reaction in Saccharomyces cerevisiae. ${ }^{13,15}$, The peptide is composed of amino acids commonly found in proteins. On the other hand, rhodotorucine $A$ is a lipophilic peptide with a novel amino acid, S-farnesylcysteine, at the C-terminus. As far as we know, this type of lipophilic peptide is the first isolated from nature as a regulatory substance. The synthetic peptide which had no alkyl side chain at the $\mathrm{C}$-terminus did not show the biological activity even at a high concentration. ${ }^{21}$ This indicated that the farnesyl moiety in rhodotorucine $A$ is indispensable for inducing the mating tube formation of $a$ type cells.

Recently, Sakagami et al. isolated a conjugation tube inducing hormone named tremerogen A-10 in Tremella mesenterica Fr. They also predicted the presence of S-alkylated cysteine at the C-terminus, though the whole structure is not yet clarified. ${ }^{16 \text { ) }}$

Rhodotorucine $A$ did not induce the mating tube formation of $T$. mesenterica Fr., and tremerogen A-10 also did not induce the mating tube formation of $R$. toruloides. This suggested the peptide sequence was also important to show biological activity. ${ }^{17}$ )

Biological study of the mating reaction in $R$. toruloides $^{18 \sim 20)}$ and the syntheses of the analo-

\section{H-Tyr-Pro-Glu-Ile-Ser-Trp-Thr-Arg-Asn-Gly-Cys-OH}

(I)

Recently, we have succeeded in the synthesis of rhodotorucine $A$ with solution method using L-amino acids, and the synthetic peptide showed the same biological activity as natural rhodotorucine $A$. This confirmed the correctness of the structure of rhodotorucine $A$. Details of the synthesis will be reported elsewhere. $^{12)}$

As for the sex hormone of yeasts, an oligo-

* We are indebted to Dr. M. Fujino (Takeda Chemical Industries Ltd.) for the synthesis of the peptide. ${ }^{12)}$ gues of rhodotorucine $A$ are in progress.

\section{EXPERIMENTAL}

Amino acid analyses were run on a Hitachi KLA$3 \mathrm{~B}$ or a JEOL JLC-6AH amino acid analyser. The PMR spectra were measured with a JEOL FX-100 or a PMX-60 spectrometer with a tetramethylsilane as an internal standard. The $\mathrm{CI}$ and $\mathrm{EI}$ mass spectra were recorded on a Hitachi RMU-6MG mass spectrometer with a direct inlet system. The high resolution EI mass spectrum was recorded with a Hitachi RMU-7M mass spectrometer. The UV spectrum was obtained 
with a Hitachi 124 spectrophotometer and UV absorptions were monitored with a ISCO UV-5 monitor. The specific rotation was measured with a JASCO DIP-180 automatic polarimeter using $10 \mathrm{~cm}$ cell. Melting points were measured on a microscope hot plate and were uncorrected.

\section{Amino acid analyses}

Rhodotorucine $A$ or each peptide fragment (50 $200 \mu \mathrm{g}$ ) was hydrolyzed with freshly distilled $0.2 \mathrm{ml}$ of $5.7 \mathrm{~N} \mathrm{HCl}$ (constant boiling) in a small evacuated tube at $105^{\circ} \mathrm{C}$ for $36 \mathrm{hr}$. When the peptide contained tryptophan, $2 \%$ thioglycolic acid was added to $\mathrm{HCl}$ and hydrolyzed in the same way. After reaction, $\mathrm{HCl}$ was evaporated over $\mathrm{KOH}$ in a vacuum desiccator and the resulting residue was subjected to the amino acid analysis.

\section{Performic acid oxidation}

A performic acid solution was prepared from $9 \mathrm{ml}$ of formic acid and $1 \mathrm{ml}$ of $30 \% \mathrm{H}_{2} \mathrm{O}_{2}$ at $0^{\circ} \mathrm{C}$ for $1 \mathrm{hr}$. Rhodotorucine $A(200 \mu \mathrm{g})$ was dissolved in $200 \mu \mathrm{l}$ of the performic acid solution and kept at $0^{\circ} \mathrm{C}$ for $4 \mathrm{hr}$. Then $30 \mu 1$ of $48 \% \mathrm{HBr}$ was added to the solution and evaporated in vacuo at $40^{\circ} \mathrm{C}$. The residue was dissolved in $100 \mu \mathrm{l}$ of water, lyophilized and hydrolyzed with $5.7 \mathrm{~N} \mathrm{HCl}$ in the same conditions as described in amino acid analyses.

\section{Dansyl Edman degradations}

$\mathrm{N}$-Terminal amino acid was determined by dansyl (DNS) method with some modifications. ${ }^{7)}$ The peptide $(2 \mu \mathrm{g})$ was treated with $2 \mu \mathrm{l}$ of $0.2 \mathrm{M} \mathrm{NaHCO}_{3}$ and $2 \mu \mathrm{l}$ of $0.3 \% \mathrm{DNS}$-chloride in acetone at $45^{\circ} \mathrm{C}$ for 30 min in a micro test tube. The product was hydrolyzed with $5.7 \mathrm{~N} \mathrm{HCl}$ at $100^{\circ} \mathrm{C}$ for $16 \mathrm{hr}$.

Edman degradation was carried out by use of $40 \mu \mathrm{g}$ of the peptide. A sample in a small stoppered tube was dissolved in $20 \mu 1$ of pyridine-water (1:1). One $\mu 1$ of phenylisothiocyanate was added to the solution and kept at $45^{\circ} \mathrm{C}$ for $90 \mathrm{~min}$ under $\mathrm{N}_{2}$ gas with occasional shaking. After lyophilization of the reactant, $20 \mu \mathrm{l}$ of trifluoroacetic acid (TFA) was added to the residue and the solution was kept at $45^{\circ} \mathrm{C}$ for $30 \mathrm{~min}$ under $\mathrm{N}_{2}$ gas. The TFA was evaporated under $\mathrm{N}_{2}$ stream, and $200 \mu$ of water was added to the residue. The water solution was shaken twice with $100 \mu \mathrm{l}$ of $n$ butyl acetate. A small portion $(10 \sim 20 \mu \mathrm{l})$ was taken from the aqueous residue for the $\mathrm{N}$-terminus determination and the remainder was lyophilized for further degradation.

The DNS-amino acid obtained at acid hydrolysis was identified by TLC on polyamide sheets $(5 \times 5 \mathrm{~cm}$, Cheng Ching Trading Co.) with two-dimensional development by the following solvent systems; A) $\mathrm{H}_{2} \mathrm{O}-$ $28 \% \mathrm{NH}_{3}\left(\mathrm{H}_{2} \mathrm{O}\right)(100: 1)$ for the first direction and $n$ - heptane- $n$-BuOH-HCOOH (10:10:1) for the second direction; B) $\mathrm{H}_{2} \mathrm{O}-\mathrm{HCOOH}(200: 3)$ for the first direction, benzene-AcOH $(9: 1)$ for the second direction and AcOEt-MeOH-AcOH $(20: 1: 1)$ for the third run in the same direction as the second. The solvent system B was found suitable for the mutual separation of DNS-Glu and DNS-Asp. ${ }^{7}$

\section{Direct Edman degradations}

Direct Edman degradation was performed by use of $200 \mu \mathrm{g}$ of rhodotorucine $A$ as described by Sauer et $_{\text {al }}{ }^{21}$. Phenylthiohydantoin amino acids were detected by TLC on polyamide sheets $(5 \times 5 \mathrm{~cm})$ with two-dimensional development by use of toluene- $n$-hexane-AcOH $(60$; 30: 16) containing butyl PBD [2-(4-t-butylphenyl)-5(4-biphenyl)-1, 3, 4-oxadiazol] as a fluoresence indicator and $\mathrm{H}_{2} \mathrm{O}-\mathrm{AcOH}(3: 1){ }^{\text {? }}$

\section{Enzymatic hydrolyses}

Rhodotorucine $A(6 \mathrm{mg})$ was dispersed in $20 \mathrm{ml}$ of $0.1 \mathrm{M}$ ammonium acetate buffer $\mathrm{pH} 7.0$ and digested with $120 \mu \mathrm{g}$ of TPCK trypsin (EC 3.4.21.4, Worthington Biochemical Co.) for $20 \mathrm{hr}$ at $30^{\circ} \mathrm{C}$. The reaction mixture was extracted with $10 \mathrm{ml}$ of $n-\mathrm{BuOH}$ three times and combined $\mathrm{BuOH}$ layers were washed twice with $10 \mathrm{ml}$ of water. The aqueous layer gave octapeptide $\mathrm{Tr}-1$ and the butanol layer gave crude $\mathrm{Tr}-2$.

$\mathrm{Tr}-1(3.0 \mathrm{mg})$ was dissolved in $3.0 \mathrm{ml}$ of $0.1 \mathrm{M} \mathrm{am}-$ monium acetate buffer pH 7.0 and digested with $30 \mu \mathrm{g}$ of $\alpha$-chymotrypsin (EC 3.4.21.1, Miles Research Products $\mathrm{Co}$.) for $18 \mathrm{hr}$ at $30^{\circ} \mathrm{C}$. The reaction mixture was concentrated and subjected to a Sephadex G-25 (Super fine, Pharmacia) column chromatography $(1.0 \times 68 \mathrm{~cm})$ eluted with $0.1 \mathrm{M} \mathrm{AcOH}$. Fractions $24 \sim$ 28 gave CT $-2(0.4 \mathrm{mg})$ and fractions $36 \sim 38$ gave CT-1 (2.3 mg).

CT-1 (1.5 mg) was dissolved in $1.5 \mathrm{ml}$ of $0.1 \mathrm{M}$ ammonium acetate buffer pH 7.0 containing $5 \mathrm{mM}$ of $\mathrm{CaCl}_{2}$ and digested with $30 \mu \mathrm{g}$ of thermolysin (EC 3.4.24.4, Daiwakasei Co. Tokyo) for $12 \mathrm{hr}$ at $40^{\circ} \mathrm{C}$. The reaction mixture was again purified with the same Sephadex G-25 column eluted with $0.1 \mathrm{M} \mathrm{AcOH}$. Fractions $23 \sim 27$ gave $\mathrm{Th}-1(0.5 \mathrm{mg})$ and fractions $31 \sim 35$ gave $\mathrm{Th}-3(0.5 \mathrm{mg})$.

Each peptide fragment $(10 \sim 20 \mu \mathrm{g})$ was digested with aminopeptidase M (EC 3.4.11.2, Protein Research Foundation, Osaka) at $30^{\circ} \mathrm{C}$ in ammonium acetate buffer $\mathrm{pH}$ 7.0, enzyme: substrate $=1: 20(\mathrm{wt} / \mathrm{wt})$. Amino acids were identified with DNS method decribed before.

\section{$T r-2$}

Crude $\mathrm{Tr}-2$ was recrystallized from aqueous methanol (fine needles, $1.29 \mathrm{mg}$ ). $R f$ values on silica gel TLC; solvent system A) $n-\mathrm{BuOH}-\mathrm{AcOH}-\mathrm{H}_{2} \mathrm{O}$ (4:1:5, upper layer) $0.47, B$ ) methylethylketone- 
pyridine- $\mathrm{AcOH}-\mathrm{H}_{2} \mathrm{O} \quad(70: 15: 2: 15) \quad 0.53$. $\mathrm{Tr}-2$ was insoluble in water and soluble in pyridine and a mixture of $\mathrm{CHCl}_{3}: \mathrm{MeOH}: \mathrm{H}_{2} \mathrm{O}(1: 1: 1)$. The PMR spectrum is shown in Fig. 3.

$\operatorname{Tr}-2(10 \sim 20 \mu \mathrm{g})$ was acetylated with a mixture of acetic anhydride and acetic anhydride $d_{6}(1: 1)$ in $10 \%$ methanol solution $(30 \mu \mathrm{l})$ for $2 \mathrm{hr}$ at toom temp. In this condition the carboxyl group was easily methylated. After evaporation of excess reagent, the residue was subjected to EI and CI mass spectrometric analyses, sample temp.; $120 \sim 180^{\circ} \mathrm{C}$, ion accelerating voltage; $20 \mathrm{eV}$ and $70 \mathrm{eV}$ (EI), $100 \mathrm{eV}(\mathrm{CI})$, reactant gas; isobutane, $99.99 \%$. Figure 3 shows a CI mass spectrum of acetylated $\mathrm{Tr}-2$ methyl ester. High resolution EI mass spectrum $\left(70 \mathrm{eV}, 140^{\circ} \mathrm{C}\right)$ of this sample revealed peaks $[\mathrm{m} / e$ observed and error (mMU)] $69.0687(-1.6)$ $\mathrm{C}_{8} \mathrm{H}_{8}, 137.1326(-0.3) \mathrm{C}_{10} \mathrm{H}_{17}, 157.0586(-2.5) \mathrm{C}_{8} \mathrm{H}_{9}$ $\mathrm{N}_{2} \mathrm{O}_{3}, 204.1874(-0.2) \mathrm{C}_{15} \mathrm{H}_{24}, 214.0803(-2.3) \mathrm{C}_{8} \mathrm{H}_{12}$ $\mathrm{N}_{3} \mathrm{O}_{4}, 237.1695$ (2.0) $\mathrm{C}_{15} \mathrm{H}_{25} \mathrm{~S}_{1}, 332.0967$ (5.2) $\mathrm{C}_{12} \mathrm{H}_{18}$ $\mathrm{N}_{3} \mathrm{O}_{6} \mathrm{~S}_{1}$.

\section{Synthesis of S-trans-trans-farnesylcysteine}

trans-trans-Farnesol was prepared from trans-geranyl acetone ${ }^{22)}$ and purified by Lobar silica gel column $(3.7 \times 44 \mathrm{~cm}$, Merck) with solvent system $n$-hexaneAcOEt (4:1) to remove slight contamination of transcis isomer. This was converted to a bromide by treatment with $\mathrm{N}$-bromosuccinimide and methylsulfide according to the procedure described by Corey. ${ }^{23)}$

Cysteine $(150 \mathrm{mg})$ and the bromide $(200 \mathrm{mg})$ were dissolved in $20 \mathrm{ml}$ of $n-\mathrm{BuOH}-\mathrm{MeOH}-\mathrm{H}_{2} \mathrm{O}$ (1:1:1). Guanidine carbonate $(150 \mathrm{mg})$ was added to the solution which was stirred at room temp. for $18 \mathrm{hr}$. After addition of $20 \mathrm{ml}$ of water to this solution, the reaction mixture was extracted three times with each $10 \mathrm{ml}$ of $n$-BuOH. Evaporation of the solvent gave crude Sfarnesylcysteine which was recrystalized from aqueous methanol $(100 \mathrm{mg}),[\alpha]_{\mathrm{D}}^{20}-30.2(c=0.01) \mathrm{mp} 148 \sim$ $150^{\circ} \mathrm{C}$ (gradually decomp.). The PMR spectrum is shown in Fig. 5. $R f$ values on silica gel TLC; solvent system A) $0.68, \mathrm{C}) \mathrm{BuOH}-\mathrm{AcOH}-$ pyridine- $\mathrm{H}_{2} \mathrm{O}(15$ : $3: 10: 12) 0.83$, CI-MS (N-Ac, OMe) $m / e: 382\left(\mathrm{M}^{+} \mathrm{H}\right)$, $350,205,178,137$ and 69.

Acknowledgments. We wish to express our thanks to Dr. K. Nakayama and Mr. S. Kon of Kyowa Hakko Co. for their cooperation in the large scale cultivations of the yeast. We are also greateful to Dr. T. Takita and Dr. H. Naganawa of the Institute of Microbial Chemistry for the measurement of high resolution mass spectrum.

\section{REFERENCES}

1) I. Banno, J. Gen. Appl. Microbiol., 13, 167 (1967).
2) K. Abe, I. Kusaka and S. Fukui, J. Bacteriol., 122, 710 (1975).

3) Y. Kamiya, K. Yamamoto, A. Sakurai, S. Tamura, K. Abe and S. Fukui, Proc. Jpn. Acad, 51, 571 (1975).

4) Y. Kamiya, A. Sakurai, S. Tamura, K. Abe, E. Tsuchiya and S. Fukui, Agric. Biol. Chem., 41, 1099 (1977); idem, ibid., 42, 1239 (1978).

5) Y. Kamiya, A. Sakurai, S. Tamura, N. Takahasi, K. Abe, E. Tsuchiya and S. Fukui, Agric. Biol. Chem., 42, 209 (1978); idem, Abstracts of Papers, 15th Symposium on Peptide Chemistry, Osaka, November, 1977, p. 157.

6) Y. Kamiya, A. Sakurai S. Tamura, N. Takahashi, K. Abe, E. Tsuchiya, S. Fukui, C. Kitada and M. Fujino, Biochem. Biophys. Res Commun., 83, 1077 (1978); idem, Abstracts of Papers, 21st Symposium on the Chemistry of Natural Products, Sapporo, August, 1978, p. 104.

7) S. Kimura, Japan Analyst, 23, 563 (1974).

8) B. S. Hartley, Biochem. J., 119, 805 (1970).

9) K. D. Kulube, Anal. Biochem., 59, 564 (1974).

10) W. R. Gray, L. H. Wojcik and J. H. Fuurell, Biochem. Biophys. Res. Commun., 41, 1119 (1970).

11) R. B. Bates and D. M. Gale, J. Am. Chem. Soc., 82, 5744 (1960).

12) M. Fujino, Y. Kamiya et al., 16th Symposium on Peptide Chemistry, Fukuoka, November, 1978, in preparation.

13) A. Sakurai, S. Tamura, N. Yanagishima and $C$. Shimoda, Agric. Biol. Chem., 40, 1057 (1970); idem, ibid., 41, 395 (1977).

14) D. Stötzler, H. Kiltz and W. Duntze, Eur. J. Biochem., 69, 397 (1976).

15) E. Ciejek, J. Thorner and M. Geier, Biochem. Biophys. Res. Commun., 78, 952 (1977).

16) Y. Sakagami, A. Isogai, A. Suzuki, S. Tamura, E. Tsuchiya and S. Fukui, Agric. Biol. Chem., 42, 1093 (1978); idem, ibid., 42, 1303 (1978).

17) E. Tsuchiya and S. Fukui, ibid., 42, 1089 (1978).

18) E. Tsuchiya, S. Fukui, Y. Kamiya, Y. Sakagami and M. Fujino, Biochem. Biophys. Res. Commun., 85, 459 (1978).

19) E. Tsuchiya and S. Fukui, ibid., 85, 473 (1978).

20) E. Tsuchiya, K, Abe and S. Fukui, J. Gen. Appl. Microbiol., 24, 287 (1978); K. Abe, E. Tsuchiya, S. Fukui, N. Kodama and A. Kusanagi, ibid., 24, 291 (1978).

21) R. T. Sauer, H. D. Niall, M. L. Hogan, H. T. Keutmann, J. L. H. O'Riordan and J. T. Potts, Jr., Biochemistry, 13, 1994 (1974).

22) I. Oguni and I. Uritani, Agric. Biol. Chem., 33, 1654 (1969).

23) E. J. Corey, C. U. Kim and M. Takeda, Tetrahedron Lett., 1972, 4339. 